\title{
Anuran Species in Kayu Tanam Area
}

\author{
Ramadhan Sumarmin $^{1, *}$, Rahmat Hidayat ${ }^{1,2}$, Rian Putra ${ }^{1,2}$, Fazli Saldayu ${ }^{1,2}$, Sausan Hanifa ${ }^{1,2}$, \\ M. Ichsan Fajri², Zia A.Z. Putra \\ ${ }^{1}$ Department of Biology, Faculty of Mathematics and Natural Sciences, Universitas Negeri Padang, Jl, Indonesia \\ ${ }^{2}$ Wildlife Observer Community, Pusat Penelitian Kependudukan dan Lingkungan Hidup (PPKLH), \\ Universitas Negeri Padang, Jl, Indonesia
}

Copyright $\bigcirc 2019$ by authors, all rights reserved. Authors agree that this article remains permanently open access under the terms of the Creative Commons Attribution License 4.0 International License

\begin{abstract}
There are two types of areas of Kayu Tanam District as highland form Anai Area and as lowland form Kapalo Hilalang. The two types of landform have been accord to frog life span of the anuran. The Anai areas have been an education-tourism area to domestic and international tourism. Koto Hilalang area have been paddy farming area without pesticides treatment. Koto Hilalang have been an education-tourism area to domestic and international tourism too. The aimed of this study to inventory and to comparison the Anuran species in two type's area of Kayu Tanam District. The data were collected using Visual Encounter Survey (VES) method modified by Time Search Method. The result showed that there are 21 species of frogs (Polypedates leucomystax, Polypedates colletti, Polypedates macrotis, Polypedates otilophus, Rhacophorus pardalis, Duttaphrynus melanostictus, Pelophryne signata, Phrynoidis asper, Kalophrynus palmatissimus, Kalophrynus pleurostigma, Microhyla heymonsi, Megophrys nasuta, Limnonectes blythii, Limnonectes kuhlii, Limnonectes malesianus, Occidozyga lima, Occidozyga sumatrana, Fejervarya cancrivora, Fejervarya limnocharis, Hylarana nicobariensis, and Hylarana erythraea) from 12 genera of six families. Only six species (Duttaphrynus melanostictus, Fejervarya cancrivora, Hylarana erythraea, Megophrys nasuta, Occidozyga sumatrana, and Polypedates leucomystax) from 21 species has found in Kapalo Hilalang.
\end{abstract}

Keywords Anura, Edutourism, Inventory, Paddy Farming, VES

\section{Introduction}

Kayu Tanam an area that is one of the destinations for both domestic and foreign tourists. Kayu Tanam has a tourist attraction due to the construction of the Malibo Anai tourism in the Anai area. This tourist area carries the concept of tourism while learning in nature. This Anai area is still surrounded by tropical forests with temperate climate and is located in high land area. One attraction for tourists is the amphibian diversity of the Anura order.

Kapalo Hilalang is also an educational tourism area with the concept of agriculture without pesticides. In this area there are still well-maintained community forests surrounded by rice fields (paddy fields). To overcome insect pests in every rice growing season, farmers are very dependent on the natural enemies of insect pests, especially frogs or frogs. Kapalo Hilalang is crossed by the Anai River. Although the Kapalo Hilalang belongs to the lowland category, it is also temperate.

Both the Anai and Kapalo Hilalang regions, for its tourist attraction, are amphibian diversity. Until now there has been no disclosure of amphibian species in the two regions. The diversity of amphibians, especially Anura, in both regions is one of the determinants of the continuation of educational tourism business.

The Order Anuran is one of the orders in the amphibian class, consisting of frogs and toads. The member of this order is identified to reach approximately 4,100 species of frogs and toads (Dubois, 2004). The spread of the Anuran (frog) is found throughout Indonesia from Sumatra, Kalimantan, Java to Papua, reaching about 450 species, which represents about $11 \%$ of all Anuran in the world (Iskandar, 1998). Brogs and toads have many differences, where the frog is easily recognizable from a typical morphology with four legs longer, unclear neck, eyes tend to be large, have mucous glands and smooth skin surface, while the skin surface on the toad is rough and has a bulge, hands and feet tendon to be shorter than frog legs. Anuran (frog) has a wide dispersal area as in all terrestrial and freshwater habitats, human settlements, trees, watersheds, and in primary and secondary forests (Stuarte et al. 2008). In general, the Order of Anura has a membrane for swimming, although some do not have membranes such as the genus Leptobrachium and Megophrys. The presence or absence of the membrane for swimming is very suitable with the habitat it occupies. The Anuran has a varied color 
based on its family such as the family of Rhacophoridae tends to be light-colored while the Megophrydae family tends to darken according to its habitat in the litter (Mistar, 2003).

Anuran habit has variations from underground to highest canopy on trees. The majority of anurans living in particular areas, especially in tropical rainforests because they have high humidity that can protect them from a variety of conditions (Ariza et al, 2014). Some anurans are habitat near the river, even some species cannot leave the water. Anurans cannot survive in salt water. However, there are types of the anuran that can be found in brackish water (Iskandar, 1998). In general, tropical rain forest areas are characterized by two seasons, rainy and dry seasons. Other conditions are high temperature and humidity, as well as rainfall, whereas soil is a factor in the tropics that does not support high productivity because it is very old soil (Walter, 1981).

Anurans play an important role in ecology as secondary consumers to help maintain the balance of ecosystems, especially in the control of insect populations. In addition, the anuran can also serve as bio-indicators for the environment because the anurans have a response to environmental changes (Stebbins and Cohen, 1997). One of the causes of decreasing conditions is the destruction of forest habitat and fragmentation. Less disturbing forests or moderately changing forests have such species as disturbed areas such as secondary forests, fields and settlements (Gillespie et al., 2005).

The aim of this research is to inventory frog species in Kayu Tanam District. The results of this research can be a reference of information to other researchers and the education tourism decision maker of government to approval.

\section{Materials and Methods}

\section{Study Area}

Study areawas studied in KayuTanam District, Padang Pariaman, West Sumatra. Data collection was collected in two locations at same times. The first data was collected in KapaloHilalang village and Anai area on April and Meito August 2017.

The area of KapaloHilalang village is $10.59 \mathrm{~km}^{2}$ consisting of four Korong namely Pasa Limau, PincuranTujuh, Simpang Balai Kamih and Tarok (altitude of 200-400 m above sea level). Nagari Kapalo Hilalang is bordered directly by Nagari Guguak in the north, Nagari Sicincin in the south, Pibado hill in the east, and western Korong district. The administrative area of Anai is 400 ha, located at the foot of Tandikat Mountain (2439 m above sea level) at an altitude of 600-700 m above sea level and dominated by tropical rainforest.

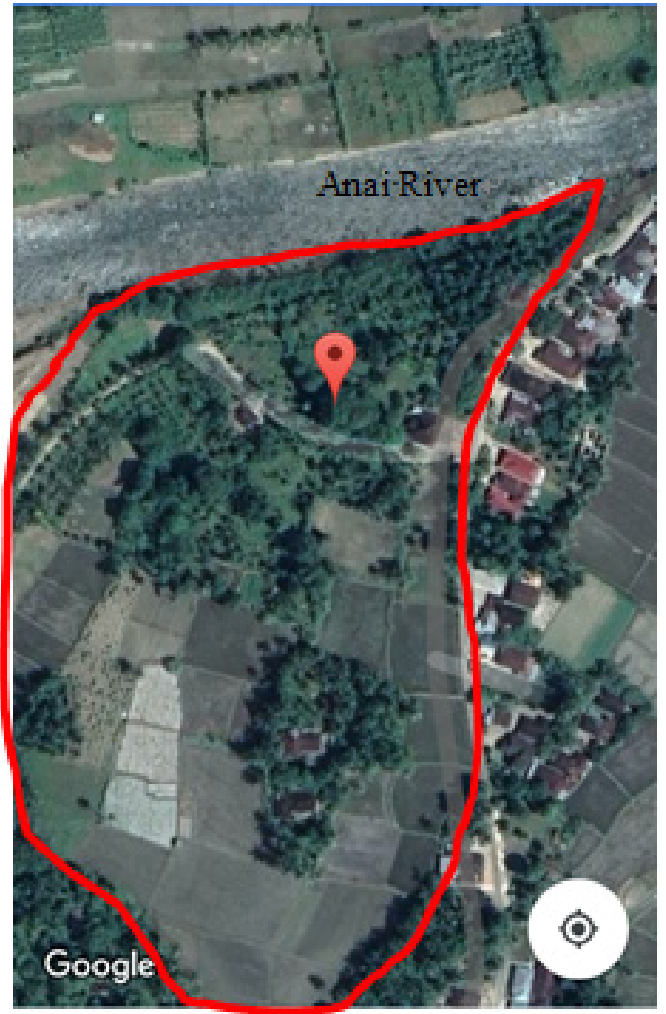

Figure 1. Kapalo Hilalang Area

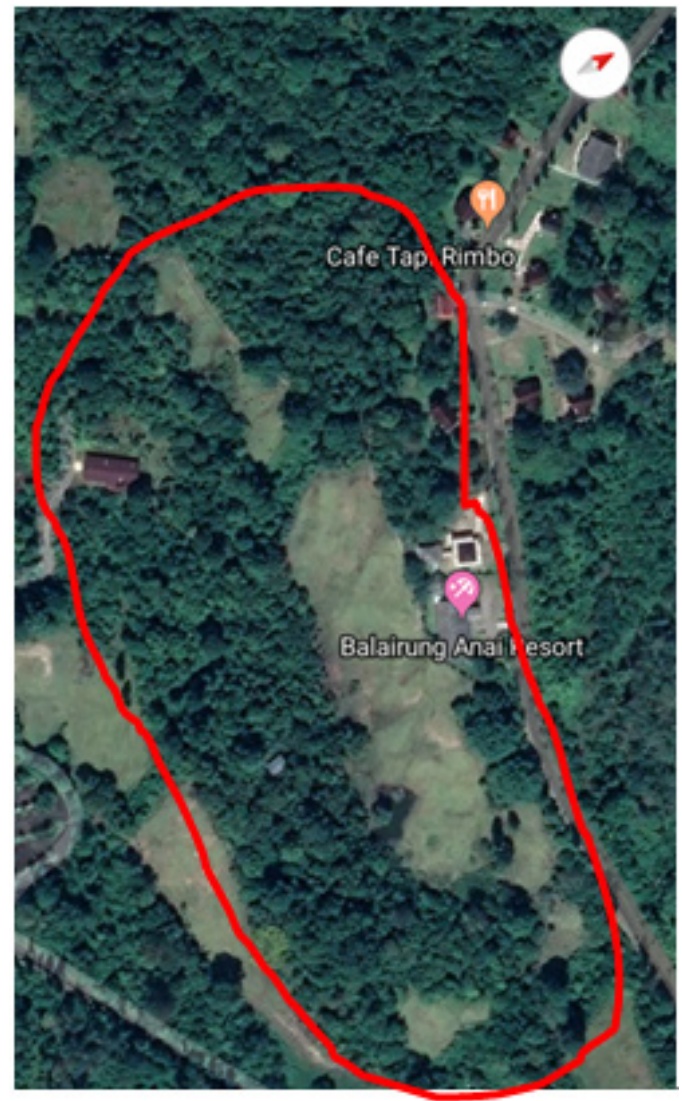

Figure 2. Anai Area 


\section{Procedures}

Data collection method used is Visual Encounter Survey (VES) which is taking the animal species based on direct encounter on the path, both in terrestrial and aquatic areas.
Visual Encounter Survey (VES) method is modified by Time Search method. Time search is a method of taking data with full time. The length of time the data was taken is predetermined and the time to record the animals is not counted.

\section{Results and Discussion}

Based on the results of data collection in Kapalo Hilalang and on Anai area has found 21 species of 12 genus of six families (Table 1).

Table 1. Anuran Species of Anai Area and Kapalo Hilalang Village of Kayu Tanam District

\begin{tabular}{|c|c|c|c|c|c|c|}
\hline No. & Family & Scientific Name & Common Name & Occurrences & IUCN Status & Location \\
\hline 1 & \multirow{3}{*}{ Bufonidae } & $\begin{array}{l}\text { Duttaphrynus melanostictus } \\
\text { (Schneider, 1799) }\end{array}$ & $\begin{array}{l}\text { Asian Common } \\
\text { Toad }\end{array}$ & Common & $\begin{array}{l}\text { Least } \\
\text { Concern }\end{array}$ & $\begin{array}{l}\text { Kapalo Hilalang } \\
\text { Village and Anai } \\
\text { Area }\end{array}$ \\
\hline 2 & & $\begin{array}{c}\text { Pelophryne signata } \\
\text { (Boulenger, 1894) }\end{array}$ & $\begin{array}{l}\text { Short-legged } \\
\text { Dwarf Toad }\end{array}$ & Common & $\begin{array}{c}\text { Near } \\
\text { Threatened }\end{array}$ & Anai Area \\
\hline 3 & & $\begin{array}{c}\text { Phrynoidis asper } \\
\text { (Gravenhorst, 1829) }\end{array}$ & Asian Giant Toad & Rare & $\begin{array}{c}\text { Least } \\
\text { Concern } \\
\end{array}$ & Anai Area \\
\hline 4 & \multirow{7}{*}{ Dicroglossidae } & $\begin{array}{l}\text { Fejervarya cancrivora } \\
\text { (Gravenhorst, 1829) }\end{array}$ & $\begin{array}{c}\text { Asian Brackish } \\
\text { Frog }\end{array}$ & Common & $\begin{array}{c}\text { Least } \\
\text { Concern }\end{array}$ & $\begin{array}{c}\text { Kapalo Hilalang } \\
\text { Village and Anai } \\
\text { Area }\end{array}$ \\
\hline 5 & & $\begin{array}{c}\text { Fejervarya limnocharis } \\
\text { (Gravenhorst, 1829) }\end{array}$ & Asian Grass frog & Rare & $\begin{array}{c}\text { Least } \\
\text { Concern } \\
\end{array}$ & Anai Area \\
\hline 6 & & $\begin{array}{c}\text { Limnonectes blythii } \\
\text { (Boulenger, 1920) }\end{array}$ & Blyth's Wart Frog & Rare & $\begin{array}{c}\text { Near } \\
\text { Threatened }\end{array}$ & Anai Area \\
\hline 7 & & $\begin{array}{l}\text { Limnonectes kuhlii } \\
\text { (Tschudi, 1838) }\end{array}$ & Kuhl's Creek Frog & Rare & $\begin{array}{c}\text { Least } \\
\text { Concern } \\
\end{array}$ & Anai Area \\
\hline 8 & & $\begin{array}{c}\text { Limnonectes malesianus } \\
\text { (Kiew, 1984) }\end{array}$ & Malesian Frog & Rare & $\begin{array}{c}\text { Near } \\
\text { Threatened }\end{array}$ & Anai Area \\
\hline 9 & & $\begin{array}{c}\text { Occidozyga lima } \\
\text { (Gravenhorst, 1829) }\end{array}$ & $\begin{array}{l}\text { Pointed-tongued } \\
\text { Floating Frog }\end{array}$ & Rare & $\begin{array}{c}\text { Least } \\
\text { Concern } \\
\end{array}$ & Anai Area \\
\hline 10 & & $\begin{array}{l}\text { Occidozyga sumatrana } \\
\text { (Peters, 1877) }\end{array}$ & $\begin{array}{l}\text { Sumatran Puddle } \\
\text { Frog }\end{array}$ & Common & $\begin{array}{c}\text { Least } \\
\text { Concern }\end{array}$ & $\begin{array}{c}\text { Kapalo Hilalang } \\
\text { Village and Anai } \\
\text { Area }\end{array}$ \\
\hline 11 & \multirow{4}{*}{ Megophrydae } & $\begin{array}{l}\text { Megophrys nasuta } \\
\text { (Schlegel, 1858) }\end{array}$ & $\begin{array}{l}\text { Long Nose } \\
\text { Horned Frog }\end{array}$ & Rare & $\begin{array}{c}\text { Least } \\
\text { Concern }\end{array}$ & $\begin{array}{c}\text { Kapalo Hilalang } \\
\text { Village and Anai } \\
\text { Area }\end{array}$ \\
\hline 12 & & $\begin{array}{l}\text { Microhyla heymonsi } \\
\text { (Vogt, 1911) }\end{array}$ & $\begin{array}{l}\text { Arcuate-spotted } \\
\text { pygmye frog }\end{array}$ & Rare & $\begin{array}{c}\text { Least } \\
\text { Concern }\end{array}$ & Anai Area \\
\hline 13 & & $\begin{array}{c}\text { Kalophrynus palmatissimus } \\
\text { (Kiew, 1984) }\end{array}$ & $\begin{array}{l}\text { Lowland Grainy } \\
\text { Frog }\end{array}$ & Rare & Endangered & Anai Area \\
\hline 14 & & $\begin{array}{c}\text { Kalophrynus pleurostigma } \\
\text { (Tschudi, 1838) }\end{array}$ & $\begin{array}{l}\text { Black-spotted } \\
\text { Sticky Frog }\end{array}$ & Rare & $\begin{array}{c}\text { Least } \\
\text { Concern }\end{array}$ & Anai Area \\
\hline 15 & \multirow[t]{2}{*}{ Ranidae } & $\begin{array}{l}\text { Hylarana erythraea } \\
\text { (Schlegel, 1837) }\end{array}$ & $\begin{array}{l}\text { Common Green } \\
\text { Frog }\end{array}$ & Common & $\begin{array}{c}\text { Least } \\
\text { Concern }\end{array}$ & $\begin{array}{c}\text { Kapalo Hilalang } \\
\text { Village and Anai } \\
\text { Area }\end{array}$ \\
\hline 16 & & $\begin{array}{l}\text { Hylarana nicobariensis } \\
\text { (Stoliczka, 1870) }\end{array}$ & $\begin{array}{l}\text { Nicobar Cricket } \\
\text { Frog }\end{array}$ & Common & $\begin{array}{c}\text { Least } \\
\text { Concern }\end{array}$ & Anai Area \\
\hline 17 & \multirow{5}{*}{ Rhacophoridae } & $\begin{array}{l}\text { Polypedates leucomystax } \\
\text { (Gravenhorst, 1829) }\end{array}$ & $\begin{array}{l}\text { Common Tree } \\
\text { Frog }\end{array}$ & Common & $\begin{array}{l}\text { Least } \\
\text { Concern }\end{array}$ & $\begin{array}{c}\text { Kapalo Hilalang } \\
\text { Village and Anai } \\
\text { Area } \\
\end{array}$ \\
\hline 18 & & $\begin{array}{c}\text { Polypedates colletti } \\
\text { (Boulanger, 1890) }\end{array}$ & Colletts-Tree Frog & Rare & $\begin{array}{c}\text { Least } \\
\text { Concern }\end{array}$ & Anai Area \\
\hline 19 & & $\begin{array}{l}\text { Polypedates macrotis } \\
\text { (Boulenger, 1891) }\end{array}$ & $\begin{array}{l}\text { Dark-eared Tree } \\
\text { frog }\end{array}$ & Rare & $\begin{array}{c}\text { Least } \\
\text { Concern }\end{array}$ & Anai Area \\
\hline 20 & & $\begin{array}{l}\text { Polypedates otilophus } \\
\text { (Boulenger, 1893) }\end{array}$ & $\begin{array}{l}\text { File-eared Tree } \\
\text { Frog }\end{array}$ & Common & $\begin{array}{c}\text { Least } \\
\text { Concern }\end{array}$ & Anai Area \\
\hline 21 & & $\begin{array}{l}\text { Rhacophorus pardalis } \\
\text { (Gunther, 1859) }\end{array}$ & $\begin{array}{l}\text { Harlequin Tree } \\
\text { Frog }\end{array}$ & Common & $\begin{array}{c}\text { Least } \\
\text { Concern }\end{array}$ & Anai Area \\
\hline
\end{tabular}


KayuTanam area has a very high tropical climate by land breeze, high rainfall, and humidity. Based on data from Table 1, it showed that anuran diversity in Anai Area is better than anuran diversity in Kapalo Hilalang. Anai Area has well environmental. Anai Area around by the tropical rain forest and there is no illegal lodging activity. These conditions can maintenance the diversity of anuran in Anai Area. The other hand, even in Kapalo Hilalang activities of paddy farming mostly without pesticides treatment, anuran diversity still low because resources of food (especially insect) not enough to anuran population and diversity. Getting food resources in Kapalo Hilalang, anuran must compete to other organism as bird with limitted sources.

In the area of Kapalo Hilalang village there were six species of frogs, those are Duttaphrynus melanostictus, Fejervarya cancrivora, Hylarana erythraea, Megophrys nasuta, Occidozyga sumatrana, and Polypedates leucomystax while in the area of Anai Area there were 21 species of frogs, as Polypedates leucomystax, Polypedates colletti, Polypedates macrotis, Polypedates otilophus, Rhacophorus pardalis, Duttaphrynus melanostictus, Pelophryne signata, Phrynoidis asper, Kalophrynus palmatissimus, Kalophrynus pleurostigma, Microhyla heymonsi, Megophrys nasuta, Limnonectes blythii, Limnonectes kuhlii, Limnonectes malesianus, Occidozyga lima, Occidozyga sumatrana, Fejervarya cancrivora, Fejervarya limnocharis, Hylarana nicobariensis, and Hylarana erythraea.

Based on the variation of habitat, the genus Polypedates and Rhacophorus are arboreal, the genus Duttaphrynus, Pelophryne, Phrynoidis, Kalophrynus, Microhyla, Megophrys, Limnonectes, and Occidozyga are terrestrial, and the genus Fejervarya and Hylarana are semi- aquatic. Based on the IUCN Red List, 21 frog species status ranging from least concern, near threatened, to endanger. The variations of habitats (Izza \& Kurniawan, 2014) or geographics (Borera, 2014) would influence the diversity of anurans. It is an important warning for us to save them from extinction.

The highly insignificant species difference in both area studies is due to environmental conditions in each area study. Anurans are bio-indicators that have a response to environmental change (Wanda, etal. 2012). Although both study areas are tropical rainforest that has very supportive condition for breeding because it has high humidity and rainfall, but the condition of the forest in Anai is still more primary or not much disturbed because it is a protected forest area and a place of ecotourism. The diversity of frog species found in Anai shows that the location is still well preserved with marked availability of abundant feed and lack of human intervention to ecosystem. Compared to the condition of Kapalo Hilalang Area that is turn into paddy farming and secondary forests, the diversity of anuran species is still low because the environment is mostly changed into paddy fields. Data collection time also affects, many of anuran are nocturnal animals, and it active at night.
It is affected on number species of anurans are found in Anai Area compared with the number of anurans species in Kapalo Hilalang.

The results of inventory showed that in Kapalo Hilalang village and Anai Area, there are 21 species of frogs from six families are Bufonidae, Ranidae, Dicroglossidae, Rhacophoridae, Microhylidae, and Megophrydae. The six families consist of 12 genera are Duttaphrynus, Pelophryne, Phrynoidis, Kalophrynus, Microhyla, Megophrys, Limnonectes, Occidozyga, Polypedates, Rhacophorus, Fejervarya, and Hylarana. The species of anurans found are Duttaphrynus melanostictus, Fejervarya cancrivora, Hylarana erythraea, Megophrys nasuta, Polypedates leucomystax, Polypedates colletti, Polypedates macrotis, Polypedates otilophus, Rhacophorus pardalis, Pelophryne signata, Phrynoidis asper, Kalophrynus palmatissimus, Kalophrynus pleurostigma, Microhyla heymonsi, Megophrys nasuta, Limnonectes blythii, Limnonectes kuhlii, Limnonectes malesianus, Occidozyga lima, Occidozyga sumatrana, Fejervarya limnocharis, and Hylarana nicobariensis.

\section{Conclusions}

Based on the results and the data of research, it can concluded that

a. The anuran diversity in Anai Area better than the anuran diversity in Kapalo Hilalang

b. There are 21 species of anuran in Kayu Tanam as Duttaphrynus melanostictus, Fejervarya cancrivora, Hylarana erythraea, Megophrys nasuta, Polypedates leucomystax, Polypedates colletti, Polypedates macrotis, Polypedates otilophus, Rhacophorus pardalis, Pelophryne signata, Phrynoidis asper, Kalophrynus palmatissimus, Kalophrynus pleurostigma, Microhyla heymonsi, Megophrys nasuta, Limnonectes blythii, Limnonectes kuhlii, Limnonectes malesianus, Occidozyga lima, Occidozyga sumatrana, Fejervarya limnocharis, and Hylarana nicobariensis.

\section{REFERENCES}

[1] Ariza, Y.S., Dewi, B.S., and Darmawan A. 2014. Anuran Diversity on Several Habitat Types Youth Camp at Hurun Village Padang Cermin Sub District Pesawaran. Journal of Silva Lestari. Vol. 2 No.1. pp. 21-29.

[2] Barrera, G.S. 2014. Geographic Variation in Incillus occidentalis (Anura:Bufonidae), an Endemic Toad From Mexico, with a Redescription of Species and Delamination of the Type Locality. Revista Mexicana de Biodiversidad 85: 414-428. 
[3] Dubois A. 2004. The Higher Nomenclature of Recent Amphibians. ALYTES, International Journal of Batrachology. Vol. 22 No. 1-2: 1-14

[4] Gillespie G., Howard S., Lockie D., Scroggie M., and Boeadi. 2005. Herpetofaunal Richness and Community Structure Off shore Islands of Sulawesi, Indonesia. Biotropica 37: 279-290.

[5] Iskandar, D.T. 1998.Amphibians of Java and Bali, LIPI Field Guide Series. Bogor: Puslitbang LIPI.

[6] Izza, Q., and Kurniawan, N. 2014. Exploration of Amphibian Species in OWA Cangar and Watu Ondo Falls, Welirang Mountain. Jounal Biotropica: Vol. 2. No. 2: 103-108

[7] Mistar. 2003. Amphibian Field Guide Leuser Ecosystem Area. Bogor: The Gibbon Foundation dan PILI-NGO Movement
[8] Mistar. 2008. Amphibian and Reptile Field Guide in Mawas Area Central Borneo Province. Mawas: BOS Foundatiion.

[9] Stebbins, R.C, and Cohen N.W. 1997. A Natural History of Amphibians. New Jersey: Princeton Univ. Pr.

[10] Stuarte, S., Michael, H., Janice, C., Neil, C., Richard, B., Pavithra, R. and Bruce, Y. 2008.Threatened Amphibians of the World. USA: Conservation International.

[11] Wanda, I. F., Novarino, W., and Tjong, D. H. 2014. The Anuran Species at Harapan Rainforest, Jambi. J. Bio. UA. 1(2)-December 2012: 99-107

[12] Walter, H. 1981. Ecology of Tropical and Sub Tropical Ecology. New York: Van No strand Reinhold Co.

[13] Wells, K.D. 2007.The Ecology and Behavior of Amphibians. London: The University of Chicago Press, Ltd. 